\title{
Cigarette consumption per adult of each sex in various countries
}

\author{
G. F. TODD \\ From the Department of Medical Statistics and Epidemiology, London School of Hygiene and Tropical Medicine
}

SUMMARY Estimates of cigarette consumption per adult male and female available from surveys in eight countries are examined and the figures of national consumption per adult implied by the surveys are compared with national averages obtained from government data and other sources. The errors likely to be found in the surveys are considered and corrected figures are calculated. Estimates are also made of cigarette consumption per woman of childbearing age.

For a number of purposes it is useful to have estimates of cigarette consumption per adult male and adult female. The trends in cigarette consumption per adult of the two sexes can be quite different, as figures for the United Kingdom (Todd, 1975) and Canada (Todd, 1978) have shown. It has also been suggested that estimates of cigarette consumption by women of childbearing age could be useful in view of the effects on the fetus attributed to smoking during pregnancy and of the possible contributions of cigarette smoking to diseases which may arise as side-effects of contraceptive pills. In order to calculate cigarette consumption per adult male and female, it is necessary to have, for each sex, estimates of the percentages who are current cigarette smokers and of the average number smoked daily. Similar figures are required by age groups of women if the level of cigarette smoking by those of childbearing age is to be estimated. All these figures can be obtained only by questioning members of the public about their smoking habits. Estimates of the percentages of cigarette smokers of each sex are available for a number of countries (for example, World Health Organisation, 1976) but there are few countries for which estimates of consumption per cigarette smoker by sex are available, and still fewer countries for which both sets of figures are available for a number of recent years.

This paper provides estimates of cigarette consumption per adult aged 15 and over of each sex in various years for eight countries for which the necessary survey data were available: Australia, Canada, Denmark, Ireland, Japan, Sweden, the United Kingdom and the United States of America. Surveys of the prevalence and levels of cigarette smoking are known to have been carried out in a number of other countries but the results have not been published. The results of surveys of the smoking habits of the public in the United Kingdom since 1956 have been published by the Tobacco Research Council (Lee, 1976). The surveys in 1965, 1971 , and 1975 are used in the present paper. Reports of seven nationwide surveys of adult smoking in the United States of America have been published by units of the US Department of Health, Education and Welfare. These were based on surveys in February 1955 for the National Cancer Institute (Haenszel et al., 1956), over the period from July 1964 to June 1965, and in June 1966 for the Division of Health Interview Statistics (United States Public Health Service, 1967 and 1970), and in the autumn of 1964 , the spring of 1966 , the spring of 1970, and in 1975 for the National Clearinghouse for Smoking and Health (United States Public Health Service, 1969; 1973; and 1976a).

In a valuable paper, Warner (1978) has examined the four surveys for the National Clearinghouse for Smoking and Health. The 1955 survey for the National Cancer Institute (Haenszel et al., 1956), the 1966 survey for the Division of Health Interview Statistics, and Warner's analyses for 1970 and 1975 are used in the present paper. The analyses for the other six countries are based on all the reports available from them.

This paper offers further evidence of the wellestablished fact that people normally understate the true prevalence and level of their cigarette smoking habits. It is therefore essential that the accuracy of sample surveys of smokers should be checked whenver possible as recommended by the International Union against Cancer (1977). This can be done by expanding the survey figures to the size 
of the national population and comparing the national cigarette consumption implied by the survey results with the national cigarette sales for the appropriate period published by the Government, the cigarette manufacturers, or others.

\section{COMPARISON OF SURVEY ESTIMATES WITH \\ KNOWN TOTALS OF NATIONAL CIGARETTE CONSUMPTION}

The figures in a few of the surveys included in the present study had already been adjusted to make them consistent with the totals of national cigarette consumption. For most of the surveys, however, it was necessary to compare the average cigarette consumption per annum per adult (sexes combined) implied by the surveys with the corresponding figure obtained by dividing the known national cigarette sales for the year by the adult population. For this purpose, the defining age has been taken as $15+$ because population figures for this range are readily available. Hand-rolled cigarettes have been excluded because surveys usually cover only manufactured cigarettes. To estimate the manufactured cigarette consumption levels from the survey figures, it was necessary to estimate the mean values corresponding to the class intervals used in each survey. This presented some difficulty for the upper open-ended class intervals (' 25 or more cigarettes a day' for Australia, or ' 41 or more cigarettes a day' for the United States of America and Japan). Rather than making arbitrary guesses, the procedure adopted has been to construct hypothetical distributions of the daily cigarette
Table 1 Assumed frequency distributions of daily cigarette consumption by smokers for estimating mean values of class intervals used in the surveys

\begin{tabular}{|c|c|c|c|c|c|}
\hline $\begin{array}{l}\text { Cigarettes } \\
\text { per day }\end{array}$ & $\begin{array}{l}\text { Males } \\
\%\end{array}$ & $\begin{array}{l}\text { Females } \\
\%\end{array}$ & $\begin{array}{l}\text { Cigarettes } \\
\text { per day }\end{array}$ & $\begin{array}{l}\text { Males } \\
\%\end{array}$ & $\begin{array}{l}\text { Females } \\
\%\end{array}$ \\
\hline \multirow[t]{2}{*}{$\begin{array}{l}\text { Less than } 5 \\
5 \\
6-9 \\
10 \\
11-14 \\
15 \\
16-19 \\
20 \\
21-24 \\
25\end{array}$} & $\begin{array}{r}8 \\
3 \\
4 \\
10 \\
5 \\
8 \\
4 \\
22 \\
5 \\
5\end{array}$ & $\begin{array}{r}15 \\
5 \\
10 \\
13 \\
7 \\
11 \\
4 \\
19 \\
5 \\
2\end{array}$ & $\begin{array}{l}26-29 \\
30 \\
31-34 \\
35 \\
36-39 \\
40 \\
41-49 \\
50 \\
51+\end{array}$ & $\begin{array}{l}3 \\
9 \\
1 \\
2 \\
1 \\
6 \\
0 \\
3 \\
0\end{array}$ & $\begin{array}{l}1 \\
4 \\
0 \\
1 \\
0 \\
2 \cdot 5 \\
0 \\
0 \cdot 5 \\
0\end{array}$ \\
\hline & & & & 100 & 100 \\
\hline
\end{tabular}

consumption for men and women smokers in the heavier smoking countries (Table 1). These distributions, which were based partially on cigarette consumption in the United Kingdom in 1972 (Lee, 1976), have then been used solely to estimate the mean values of the class intervals adopted in the various surveys. This procedure has been used for Australia, Canada, Denmark, Japan and Sweden. For the United States of America, the corresponding estimates of Haenszel et al. (1956) have been used. For Ireland, figures for consumption per adult have been provided by the manufacturers. In some countries such as Denmark and Sweden, the estimated mean values may have been too high.

For each survey, cigarette consumption was calculated for the age groups actually covered by the survey and compared with the consumption per adult $(15+)$ calculated by Lee (1975) on the basis of national cigarette sales and the population aged

Table 2 Comparison of estimates (unadjusted) of numbers manufactured cigarettes smoked per adult male, per adult female and per adult (males and females combined) per year in various countries, according to surveys of smokers, with national consumption per adult

\begin{tabular}{|c|c|c|c|c|c|c|c|c|}
\hline Country & Year & $\begin{array}{l}\text { Ages } \\
\text { covered }\end{array}$ & $\begin{array}{l}\text { Consumption } \\
\text { Per adult } \\
\text { male }\end{array}$ & $\begin{array}{l}\text { from sample } \\
\text { Per adult } \\
\text { female }\end{array}$ & $\begin{array}{l}\text { surveys } \\
\text { Per adult }\end{array}$ & $\begin{array}{l}\text { Consumption } \\
\text { per adult aged } \\
\text { IS }+ \text { based on } \\
\text { total national } \\
\text { consumption }\end{array}$ & $\begin{array}{l}\text { Difference } \\
\%\end{array}$ & $\begin{array}{l}\text { Adjustment } \\
\text { factor }\end{array}$ \\
\hline Australia & $\begin{array}{l}1974 \\
1976\end{array}$ & $\begin{array}{l}16+ \\
16+\end{array}$ & $\begin{array}{l}2867 \\
2847\end{array}$ & $\begin{array}{l}1601 \\
1819\end{array}$ & $\begin{array}{l}2234 \\
2333\end{array}$ & $\begin{array}{l}3100 \\
3121\end{array}$ & $\begin{array}{l}-27 \cdot 9 \\
-25 \cdot 2\end{array}$ & $\begin{array}{l}1 \cdot 39 \\
1 \cdot 34\end{array}$ \\
\hline Canada & $\begin{array}{l}1965 \\
1970 \\
1974\end{array}$ & $\begin{array}{l}15+ \\
15+ \\
15+\end{array}$ & $\begin{array}{l}3627 \\
3314 \\
3085\end{array}$ & $\begin{array}{l}1642 \\
1790 \\
1809\end{array}$ & $\begin{array}{l}2632 \\
2546 \\
2441\end{array}$ & $\begin{array}{l}3310 \\
3340 \\
3530\end{array}$ & $\begin{array}{r}-20 \cdot 5 \\
-23 \cdot 8 \\
-30.8\end{array}$ & $\begin{array}{l}1 \cdot 26 \\
1 \cdot 31 \\
1 \cdot 45\end{array}$ \\
\hline Denmark & $\begin{array}{l}1952-53 \\
1954\end{array}$ & $\begin{array}{l}15+ \\
15+\end{array}$ & $\begin{array}{l}1152 \\
1056\end{array}$ & $\begin{array}{l}863 \\
852\end{array}$ & $\begin{array}{r}1005 \\
952\end{array}$ & $\begin{array}{l}1220 \\
1200\end{array}$ & $\begin{array}{l}-17 \cdot 6 \\
-20 \cdot 7\end{array}$ & $\begin{array}{l}1 \cdot 21 \\
1 \cdot 26\end{array}$ \\
\hline Republic of Ireland & $\begin{array}{l}1961 \\
1967 \\
1971 \\
1975\end{array}$ & $\begin{array}{l}16+ \\
16+ \\
16+ \\
16+\end{array}$ & $\begin{array}{l}3989 \\
3620 \\
3950 \\
3970\end{array}$ & $\begin{array}{l}1356 \\
1773 \\
2125 \\
2555\end{array}$ & $\begin{array}{l}2685 \\
2685 \\
3035 \\
3260\end{array}$ & $\begin{array}{l}2744^{*} \\
2813^{*} \\
2920^{*} \\
3562^{*}\end{array}$ & $\begin{array}{r}2.2 \\
-4.6 \\
+3.9 \\
-8.5\end{array}$ & $\begin{array}{l}1.02 \\
1.05 \\
0.96 \\
1.09\end{array}$ \\
\hline Japan & $\begin{array}{l}1970 \\
1971 \\
1972 \\
1973 \\
1974\end{array}$ & $\begin{array}{l}20+ \\
20+ \\
20+ \\
20+ \\
20+\end{array}$ & $\begin{array}{l}5434 \\
5503 \\
5799 \\
6003 \\
6170\end{array}$ & $\begin{array}{l}592 \\
562 \\
558 \\
635 \\
696\end{array}$ & $\begin{array}{l}2926 \\
2944 \\
3084 \\
3222 \\
3334\end{array}$ & $\begin{array}{l}2810 \\
2950 \\
3100 \\
3240 \\
3220\end{array}$ & $\begin{array}{l}+4.1 \\
-0.2 \\
-0.5 \\
+0.6 \\
+3.5\end{array}$ & $\begin{array}{l}0.96 \\
1.00 \\
1.01 \\
1.01 \\
0.97\end{array}$ \\
\hline Sweden & 1963 & $18-69$ & 1568 & 800 & 1186 & 1310 & $-9 \cdot 5$ & $1 \cdot 10$ \\
\hline USA & $\begin{array}{l}1955 \\
1966\end{array}$ & $\begin{array}{l}18+ \\
18+\end{array}$ & $\begin{array}{l}3763 \\
3917\end{array}$ & $\begin{array}{l}1309 \\
2171\end{array}$ & $\begin{array}{l}2471 \\
2990\end{array}$ & $\begin{array}{l}3270 \\
3830\end{array}$ & $\begin{array}{l}-24 \cdot 4 \\
-21 \cdot 9\end{array}$ & $\begin{array}{l}1 \cdot 32 \\
1 \cdot 28\end{array}$ \\
\hline
\end{tabular}

*After deducting $2 \%$ for domestic cigarette sales to non-residents. 
$15+$. In comparing the two sets of figures, sales to children under 15 were assumed to be negligible and disregarded. Only one adjustment was made to the figures of domestic sales. Ireland has considerable sales of cigarettes to foreign tourists, and total sales were reduced by $2 \%$ to cover this category.

The resulting estimates are summarised in Table 2. This also shows the percentage differences of the survey estimates from the national average consumption per adult and the ratio ('adjustment factor') by which the survey figures should be multiplied in order to agree with the national average. The differences contain two components: those due to differences (if any) between the figures of the age groups covered in the surveys and those for adults aged $15+$, and the errors in the surveys (usually much the larger component). The survey figures in Table 2 were obtained from the following sources: Australia from Gray and Hill $(1975 ; 1977)$; Canada from Hackland (1976); Denmark from Hamtoft and Lindhardt (1955; 1956); Republic of Ireland as noted later; Japan from Japan Tobacco and Salt Public Corporation (1975); Sweden from Central Bureau of Statistics (1960); and United States of America from United States Public Health Service (1970).

The differences shown in Table 2 between the survey estimates and the national figures were substantial in Australia, Canada, Denmark, and the United States of America. Thompson (1978) and Todd (1978) have commented on the differences between the survey and national totals in Canada. Hamtoft and Lindhardt (1956) recognised that there were considerable differences between the corresponding figures from Denmark. Warner (1978) has drawn attention to the deficits implied by US survey figures in 1964, 1966, 1970, and 1975 compared with known national totals. On the other hand, the average cigarette consumption per adult aged $20+(1970-74)$ implied by the Japanese surveys was remarkably close to the national average for adults aged $15+$. If the Japanese survey figures were converted to averages per adult aged $15+$ they would be reduced slightly, since the younger people presumably smoked less.

\section{ADJUSTMENT OF SURVEY FIGURES}

Where the survey figures diverged seriously from the national averages, some adjustment was necessary. Errors were likely to have occurred in the estimates both of the percentages of cigarette smokers and of the levels of consumption per cigarette smoker. Unfortunately, the errors could not be allocated accurately between these two factors, so it was simpler to correct the survey estimates of consumption per adult by multiplying them by the adjustment factors. The results are given in Table 3 . The assumption has been made that the errors in the surveys were in the same proportions in the two sexes. Table 3 also includes the adjusted survey estimates available for the United Kingdom (Lee, 1976), for Canada by quinquennia (Todd, 1978), and for Denmark in 1975 (Nielsen and Krarup, 1976). Warner's figures for the United States of America in 1970 and 1975 have been included, converted from consumption per cigarette smoker aged $12+$ to consumption per adult aged $15+$, using the reports on teenage smoking of the National Clearinghouse for Smoking and Health (United States Public Health Service, 1972; 1976b) and adjusted to achieve consistency with national totals.

Table 3 Adjusted estimates (to nearest 50 cigarettes) of cigarette consumption per adult per year in various countries

\begin{tabular}{|c|c|c|c|c|c|}
\hline \multirow[b]{2}{*}{ Country } & \multirow[b]{2}{*}{ Year } & \multicolumn{4}{|c|}{ Cigarette consumption per year } \\
\hline & & $\begin{array}{l}\text { Adult } \\
\text { male } \\
\text { (aged 15+) }\end{array}$ & $\begin{array}{l}\text { Adult } \\
\text { female } \\
\text { (aged 15+) }\end{array}$ & $\begin{array}{l}\text { Woman of } \\
\text { childbearin } \\
\text { Age used }\end{array}$ & $\begin{array}{l}\text { ng age } \\
\text { Cigarettes }\end{array}$ \\
\hline Australia & $\begin{array}{l}1974 \\
1976\end{array}$ & $\begin{array}{l}4000 \\
3800\end{array}$ & $\begin{array}{l}2250 \\
2450\end{array}$ & $\begin{array}{l}16-39 \\
16-39\end{array}$ & $\begin{array}{l}2550 \\
2900\end{array}$ \\
\hline Canada & $\begin{array}{l}1961-65 \\
1966-70 \\
1971-75\end{array}$ & $\begin{array}{l}4450 \\
4450 \\
4300\end{array}$ & $\begin{array}{l}1900 \\
2250 \\
2600\end{array}$ & $\begin{array}{l}15-44 \\
15-44 \\
15-44\end{array}$ & $\begin{array}{l}2200 \\
2600 \\
3000\end{array}$ \\
\hline Denmark & $\begin{array}{l}1952-54 \\
1975\end{array}$ & $\begin{array}{l}1350 \\
1700\end{array}$ & $\begin{array}{l}1050 \\
1450\end{array}$ & $15-49$ & 1600 \\
\hline $\begin{array}{l}\text { Republic of } \\
\text { Ireland* }\end{array}$ & $\begin{array}{l}1961 \\
1967 \\
1971 \\
1975\end{array}$ & $\begin{array}{l}4100 \\
3850 \\
3800 \\
4350\end{array}$ & $\begin{array}{l}1400 \\
1850 \\
2050 \\
2800\end{array}$ & $\begin{array}{l}16-49 \\
16-44 \\
16-44 \\
16-44\end{array}$ & $\begin{array}{l}1450 \\
2000 \\
2250 \\
3250\end{array}$ \\
\hline Japan & $\begin{array}{l}1970 \\
1971 \\
1972 \\
1973 \\
1974\end{array}$ & $\begin{array}{l}5200 \\
5500 \\
5850 \\
6050 \\
6000\end{array}$ & $\begin{array}{l}\mathbf{5 5 0} \\
550 \\
550 \\
650 \\
700\end{array}$ & & \\
\hline Sweden & 1963 & 1750 & 900 & $18-49$ & 1150 \\
\hline UK & $\begin{array}{l}1965 \\
1971 \\
1975\end{array}$ & $\begin{array}{l}3600 \\
3700 \\
3750\end{array}$ & $\begin{array}{l}1850 \\
2150 \\
2500\end{array}$ & $\begin{array}{l}15-44 \\
15-44 \\
15-44\end{array}$ & $\begin{array}{l}2350 \\
2750 \\
3100\end{array}$ \\
\hline USA & $\begin{array}{l}1955 \\
1966 \\
1970 \\
1975\end{array}$ & $\begin{array}{l}4950 \\
5000 \\
4750 \\
4650\end{array}$ & $\begin{array}{l}1750 \\
2800 \\
2700 \\
2950\end{array}$ & $\begin{array}{l}18-44 \\
18-44\end{array}$ & $\begin{array}{l}2350 \\
3450\end{array}$ \\
\hline
\end{tabular}

-After deducting $2 \%$ for domestic cigarette sales to non-residents.

CIGARETTE CONSUMPTION BY WOMEN OF CHILDBEARING AGE

Where the further necessary information was available, cigarette consumption per woman of childbearing age was calculated and included in Table 3. The estimates for Canada and the United Kingdom were based on adjusted survey figures. For other countries, the ratio of consumption per woman of childbearing age to consumption per adult female was estimated from unadjusted figures of female cigarette consumption by age, and applied to the adjusted figures of consumption per adult female aged $15+$ (given in rounded form in Table 3). 


\section{Discussion}

It has always been difficult to obtain accurate and unbiased information in surveys of smoking habits. Much depends, as experience in the United Kingdom, for example, has shown, on the precise wording and context of questions. Under-statements seem particularly likely to arise if questions about smoking are asked after questions about health or in a health context. It also seems likely that many smokers, and especially heavy smokers, are now reacting to anti-smoking propaganda by no longer answering questions about their smoking habits accurately, if they answer them at all.

The crucial step in calculating the estimates in Table 3 was the assumption that the errors in the unadjusted survey figures were similar in the two sexes. Is this assumption likely to have been justified? When the error in overall cigarette consumption per adult estimated by the survey was less than $10 \%$, as in Ireland, for example, the assumption is probably reasonable. However, errors of between $20 \%$ and $40 \%$ suggest some fundamental defect in the survey, and the assumption then becomes more questionable. If the procedure in the survey implied in some way that smoking was bad for health, then it is likely that women may have been more reluctant than men to admit to smoking, especially heavy smoking, and that the figures of cigarette consumption by women involved larger errors of under-statement than those of men. The same may also be true of statements made by women as proxies. Since the adjusted survey averages in Table 3 are consistent with the national averages, then if the estimated cigarette consumption per adult of one sex is too high, that of the other sex is too low.

The largest recorded under-statement of national smoking habits occurred in the surveys in 1970 and 1975 for the United States National Clearinghouse for Smoking and Health. According to figures given by Warner (1978), the survey figures had to be increased by $52 \%$ in 1970 and by $56 \%$ in 1975 to become consistent with known national totals. On the other hand, a new feature had been introduced into the 1970 and 1975 questionnaires: at the outset, respondents were asked how strongly or mildly they agreed or disagreed with a number of statements like these:

'Cigarette smoking frequently causes disease and death'.

'Teachers should set a good example by not smoking cigarettes'.

'Smoking is enough of a health hazard for something to be done about it'.

In the 1970 questionnaire there were also some favourable statements on which respondents were asked to express their views, such as 'Cigarette smoking helps people to relax' and 'Cigarettes are pleasurable'. These statements were omitted from the 1975 questionnaire, when the statement least unfavourable to smoking then posed was: 'The whole problem of cigarette smoking and health is a very minor one'. The effect must have been to remind respondents at the start of the interview that many people regarded cigarette smoking as dangerous. Only after this introductory question were they asked about their own smoking habits, so it is not surprising that these surveys should have produced record under-statements of smoking habits. Moreover, as has just been suggested, the errors of under-statement made by women may have been larger than those made by men. The effect of anti-smoking propaganda on the validity of answers to questions about smoking habits has never been investigated. It would seem wiser, therefore, to regard with some reservations those figures in Table 3 based on adjustment factors (Table 2) in excess of about $1 \cdot 3$.

The estimates of cigarette consumption per woman of childbearing age were made in order to follow up a suggestion by the late Professor D. D. Reid of the London School of Hygiene.and Tropical Medicine. The Irish Tobacco Manufacturers Advisory Committee have provided the data on cigarette smoking in the Republic of Ireland, and their Secretary, Mr. R. W. Byers, has made the calculations necessary to provide figures in the form required for Tables 1 and 2. The author thanks the committee and Mr. Byers.

Reprints from G. F. Todd, London School of Hygiene and Tropical Medicine, Keppel Street, London WC1E 7HT.

\section{References}

Central Bureau of Statistics of Sweden (1960). Smoking habits in Sweden: a mail survey. Central Bureau of Statistics: Stockholm.

Gray, N. J., and Hill, D. J. (1975). Patterns of tobacco smoking in Australia I. Medical Journal of Australia, 2, 819-822.

Gray, N. J., and Hill, D. J. (1977). Patterns of tobacco smoking in Australia II. Medical Journal of Australia, 2, 327-328.

Hackland, S. (1976). Smoking habits of Canadians, 1965-1974. Report Series No. 1. Department of Health and Welfare of Canada: Ottawa.

Haenszel, W., Shimkin, M. B., and Miller, H. P. (1956). Tobacco smoking patterns in the US. Public Health Monograph No. 45, US Department of Health, Education and Welfare: Washington DC. 
Hamtoft, H., and Lindhardt, M. (1955). Tobacco consumption in Denmark I. Danish Medical Bulletin, 2, 213-220.

Hamtoft, H., and Lindhardt, M. (1956). Tobacco consumption in Denmark II. Danish Medical Bulletin, 3, 188-196.

International Union against Cancer (1977). Workshop on Standardisation of Measurement of Cigarette Smoking Rates. Workshop recommendation in Lung Cancer Prevention, pp. 85-92. Technical Report Series, Vol. 28. International Union against Cancer: Geneva.

Japan Tobacco and Salt Public Corporation (1975). Data concerning smoking in Japan. Japan Tobacco and Salt Public Corporation: Tokyo.

Lee, P. N. (1775). Tobacco consumption in various countries. Tobacco Research Council Research Paper No. 6, 4th edition. Tobacco Research Council: London.

Lee, P. N. (1976). Statistics of smoking in the UK, pp. 62-63. Tobacco Research Council Research Paper No. 1, 7th edition. Tobacco Research Council: London.

Nielsen, P. E., and Krarup, N. B. (1976). Tobaksforbruget i Danmark, 1920-75. Ugeskrift for Laeger, 138, 2511-2516.

Thompson, M. E. (1978). Statistics of smoking in Canada. Department of Statistics, University of Waterloo: Ontario.

Todd, G. F. (1975). Changes in smoking patterns in the UK. Tobacco Research Council Occasional Paper No. 1. Tobacco Research Council: London.

Todd, G. F. (1978). An estimate of manufactured cigarette consumption by sex, age, and cohort in Canada, 1921-75. Department of Statistics, University of Waterloo: Ontario.
United States Public Health Service (1967). Cigarette smoking and health characteristics, US, July 1964 June 1965. National Center for Health Statistics, Series 10, No. 34. US Department of Health, Education and Welfare: Washington DC.

United States Public Health Service (1969). Use of tobacco: practices, attitudes, knowledge and beliefs, US, Fall 1964 and Spring 1966. US Department of Health, Education and Welfare: Washington DC.

United States Public Health Service (1970). Changes in cigarette smoking habits between 1955 and 1966. National Center for Health Statistics, Series 10, No. 59. US Department of Health, Education and Welfare: Washington DC.

United States Public Health Service (1972). Teenage smoking: national patterns of cigarette smoking, ages 12 through 18, in 1968 and 1970. US Department of Health, Education and Welfare: Washington DC.

United States Public Health Service (1973). Adult use of tobacco, 1970. US Department of Health, Education and Welfare: Washington DC.

United States Public Health Service (1976a). Adult use of tobacco, 1975. US Department of Health, Education and Welfare: Washington DC.

United States Public Health Service (1976b). Teenage smoking: national patterns of cigarette smoking, ages 12 through 18, in 1972 and 1974. US Department of Health, Education and Welfare: Washington DC.

Warner, K. E. (1978). Possible increases in the underreporting of cigarette consumption. Journal of the American Statistical Association, 73, 314-318.

World Health Organisation (1976). Survey on smoking and health in the European Region, 1974-75. WHO: Copenhagen. 